\title{
Orient po polsku. Obraz orientu w polskiej leksykografii
}

\section{Słowo wstępne}

Obecnie badacze z kręgu nauk humanistycznych, w szczególności językoznawcy i kulturoznawcy, zgadzają się, że kultura oraz doświadczenie danej społeczności i jej sposób myślenia znajdują swoje odbicie w języku, jakim dana społeczność się posługuje. Język jest swoistym magazynem pojęć, zawiera w sobie sądy posługującej się nim grupy ludzi na temat nazywanych przy jego pomocy obiektów i zjawisk. W związku z tym, że język jest wytworem człowieka, a nie tworem samoistnym, mamy tu do czynienia z oddziaływaniem dwustronnym ludzkie doświadczenie znajduje odzwierciedlenie w języku, z kolei język kształtuje sposób postrzegania rzeczywistości przez posługujące się nim społeczność i jednostkę. W obliczu tak funkcjonujących mechanizmów język, którym się posługujemy, ma bezpośredni wpływ na nasz sposób rozumowania i doświadczania otaczających nas zjawisk. Nie bez powodu mówi się, że poznając język obcy, poznajemy nowy świat i rozwijamy swój światopogląd o treści zawarte w języku, którego się uczymy. Nowy kod językowy umożliwia bowiem odmienny sposób dekodowania rzeczywistości. Poprzez analizę języka ze wszystkimi jego komponentami, ze szczególnym naciskiem kładzionym na leksykę i gramatykę, jesteśmy w stanie lepiej poznać i zrozumieć posługującą się nim społeczność, wniknąć w jej myśli i zrozumieć sposób, w jaki kategoryzuje i postrzega świat (Bartmiński 2013: 530).

Poprzez spojrzenie na to, do jakiej rzeczywistości pozajęzykowej odnosi się w języku polskim słowo orient, jesteśmy w stanie lepiej pojąć, jak Polacy rozumieją to słowo i, w związku z tym — jak postrzegają orient.

W niniejszym artykule przeanalizowane zostanie słowo orient $\mathrm{i}$ wszystkie jego derywaty, przede wszystkim przymiotnik orientalny i funkcjonujący zarów- 
no w literaturoznawstwie, jak i w językoznawstwie termin orientalizm. Zakres badań stanowią słowniki ogólne języka polskiego, encyklopedia języka polskiego, słowniki synonimów i wyrazów bliskoznacznych, słowniki wyrazów obcych, słowniki etymologiczne, słownik terminów literackich, słowniki literatury: staropolskiej, oświecenia, XIX i XX wieku oraz dostępne w sieci: Wielki słownik języka polskiego, Narodowy Korpus Języka Polskiego i Stowosieć. W celu zobrazowania najbardziej współczesnych i potocznych sposobów użycia interesujących terminów analizie poddano również proponowane wyniki wyszukiwania uzyskane przy pomocy wyszukiwarki internetowej Google.

Zebrane na podstawie przytoczonych źródeł informacje zostały skompilowane, zestawione i porównane w celu ustalenia obrazu orientu w języku i kulturze polskiej. Artykuł skupia się przede wszystkim na tym, co jest określane mianem orientu w ujęciu geograficznym, jak zmieniał się obraz orientu w czasie oraz czy orient i jego derywaty mają w polszczyźnie wydźwięk pozytywny, czy negatywny. Analizie poddano również system kolokacji objętych badaniem słów w języku polskim — ustalono, z jakimi innymi określeniami zazwyczaj idą w parze oraz w jakim kontekście występują, co pozwala na określenie wartościowania, jakiemu słowa są poddawane w języku i z czym się kojarzą jego użytkownikom. Skojarzenia są bowiem istotną częścią języka i silnie wpływają na budowanie obrazu świata.

\section{Definicje i etymologia}

W celu rekonstrukcji językowego obrazu orientu w polszczyźnie w pierwszej kolejności należy przyjrzeć się definicjom terminu oraz jego etymologii.

W Stowniku etymologicznym autorstwa Andrzeja Bańkowskiego orient opisany został jako termin wywodzący się z łacińskiego terminu orientalis, pochodzącego z kolei od również łacińskiego orientis, oznaczającego wschód (Bańkowski 2000: 428). Orient jako wschód pojawia się również w Słowniku synonimów pod redakcją Zofii Kurzowej (Kurzowa 2000: 244, 453) . Z kolei w Wielkim stowniku wyrazów obcych i trudnych autorstwa Andrzeja Markowskiego i Radosława Pawelca orient oznacza kraje wschodu, zwłaszcza Azji i Afryki Północno-Wschodniej (Markowski, Pawelec 2007: 549). Używająć tych trzech przytoczonych definicji, można wstępnie nakreślić profil słowa orient jako wyrazu bliskoznacznego do słowa wschód.

Dalszych informacji dostarcza analiza derywatów słowa orient: orientalny, orientalistyka oraz orientalizm.

W Wielkim stowniku wyrazów obcych i trudnych orientalny to tyle, co 'związany z orientem' (Markowski, Pawelec 2007: 549). U Zofii Kurzowej natomiast orientalny to wschodni, ale także kresowy i bizantyjski (Kurzowa 2000: 244, 453), 
na co wskazuje również definicja w Słowniku wyrazów bliskoznacznych Anny Kubisy-Ślipko, która dodatkowo podkreśla antonimiczny stosunek między przymiotnikami orientalny i lokalny (Kubisa-Ślipko 2000: 57). Dodatkowych informacji dostarcza definicja pochodząca z Wielkiego słownika języka polskiego, która głosi, że orientalny to taki, który jest ,charakterystyczny dla kultur pochodzących z Bliskiego, Środkowego i Dalekiego Wschodu" (Wielki słownik...).

Znacznie bardziej rozwinięte i skonkretyzowane są definicje pojęcia orientalistyka. U Markowskiego i Pawelca występuje ona jako nauka o językach i kulturach orientu, co samo w sobie nie wnosi nic nowego do poprzednio omówionych definicji. W dalszej kolejności opis zostaje jednak doprecyzowany i ogólne stwierdzenie ,języki i kultury orientu" (Markowski, Pawelec 2007: 549) jest uzupełnione o ,język hebrajski i hieroglify egipskie" (Markowski, Pawelec 2007: 549), nakreślając wyraźniejsze ramy geograficzne odpowiadające wcześniej przytoczonemu opisowi z Wielkiego słownika języka polskiego. Wciąż mamy jednak do czynienia z terminem niezwykle szerokim, co tylko potwierdza definicja zawarta w Stowniku terminów literackich pod redakcją Janusza Sławińskiego, opisująca orientalistykę jako dział filologii badający języki, literaturę i kulturę Azji i Afryki Północnej, w którego zakres wchodzą: sinologia, hebraistyka i arabistyka. Sławiński zaznacza również, że punktem wyjścia do powstania tej dyscypliny były zainicjowane w średniowieczu badania nad Biblią, prowadzące do zainteresowania językami, w jakich została ona spisana (Sławiński 2000: 58, 361).

Spośród analizowanych derywatów słowa orient najwięcej informacji dostarczają definicje leksemu orientalizm, są bowiem najbardziej rozbudowane i mają dwojaki charakter.

$\mathrm{Z}$ jednej strony orientalizm traktowany jest jako wyraz lub konstrukcja językowa przejęta z języków wschodnich, jak opisują to zjawisko Markowski i Pawelec (2007: 549). W podobny sposób przedstawia się definicja w Encyklopedii języka polskiego Stanisława Urbańczyka, gdzie dochodzi jednak do pewnego zawężenia i skupienia się na zapożyczeniach z języka tureckiego oraz perskiego i arabskiego, które stanowiły najpopularniejszy typ orientalizmów obecny w polszczyźnie od XV wieku, a najbardziej rozpowszechniony w XVII wieku. Zapożyczenia te dotyczyły głównie militariów oraz tekstyliów i wynikały z nasilonych w owym czasie kontaktów z Turcją, Tatarami Krymskimi i Ormianami (Urbańczyk 1992: 237). Definicja ta wyraźnie skupia się na Bliskim Wschodzie, pomijając inne - wcześniej wzmiankowane - obszary geograficzne, co powoduje konkretne profilowanie terminu i jego wyraźne zawężenie.

Drugi, odmienny sposób ujęcia orientalizmu proponuje Sławiński — w jego definicji jest on tożsamy z zainteresowaniem i fascynacją rozmaitymi przejawami życia i kultury narodów wschodu, szczególnie kultur: arabskiej, perskiej, hinduskiej, a także chińskiej i japońskiej (Sławiński 2000: 58, 361). Taki sposób ujęcia problemu nie tylko poszerza dotychczasowe ramy geograficzne, wyszczególniając kraje Dalekiego Wschodu uznawane za orientalne, lecz także pozwala na ze- 
branie informacji dotyczących chronologii zmian zachodzących w postrzeganiu orientu przez użytkowników języka polskiego.

Dalsza analiza definicji orientalizmu występujących w słownikach poświęconych kolejnym epokom literackim pozwoli na rekonstrukcję językowego obrazu orientu w polszczyźnie w perspektywie diachronicznej.

\section{Okres staropolski}

W Stowniku literatury staropolskiej pod redakcją Teresy Michałowskiej orientalizm jest pojmowany jako wpływ literatur wschodnich — przede wszystkim perskiej, arabskiej, tureckiej, hebrajskiej oraz indyjskiej — na literaturę polską. Silnie zaznaczył się również wpływ kultury tatarskiej oraz kręgu biblijnego. Słownik wspomina także o pomniejszych wpływach japońskich, jednak tylko w kontekście żywotów misjonarzy, którzy zginęli śmiercią męczeńską w Kraju Kwitnącej Wiśni (Majewska (red. Michałowska) 1990: 525-534, 915-924). Warto zauważyć, że po raz kolejny dochodzi tutaj do rozbudowania profilu geograficznego, tym razem o niewyszczególniane wcześniej Indie.

Okres baroku przyniósł wyraźne zawężenie terminu orientalizm. W tym czasie orientalne znaczyło to samo, co arabskie, ewentualnie tureckie lub tatarskie. Warto jednak zaznaczyć, że w dalszym ciągu wschód (orient) miał różne oblicza. Występował głównie pod postacią kultury muzułmańskiej reprezentowanej przez kultury arabską, turecką, ale również tatarską, i to nie tylko Tatarów z Krymu, lecz także określanych mianem Tatarów plemion mongolskich, które stanowią jedyny element dalekowschodni. Co ciekawe, orient miał też oblicze bardziej „swojskie”, a więc chrześcijańskie, pod postacią wpływów kultury ormiańskiej (Majewska (red. Michałowska) 1990: 525-534, 915-924).

W okresie staropolskim doszło również do niezwykle interesującego zjawiska, w którym orient, etymologicznie odnoszący się, co już zostało wcześniej ustalone, do wschodu, występował na geograficznym zachodzie - miało to miejsce w czasie panowania muzułmanów na Półwyspie Iberyjskim (Majewska (red. Michałowska) 1990: 525-534, 915-924).

\section{Okres oświecenia}

Pod względem profilowania terminu i wyłaniającego się na jego podstawie obrazu orientu w języku polskim okres oświecenia nie przyniósł większych zmian w stosunku do okresu staropolskiego. W Stowniku literatury polskiego oświecenia pod redakcją Teresy Kostkiewiczowej orientalizm definiowany jest jako zespół różnorodnych tendencji nawiązywania do kultury narodów Wschodu, ze szcze- 
gólnym naciskiem kładzionym na Turcję, Persję, Indie, kraje arabskie i Chiny (Reychman (red. Kostkiewiczowa) 1996: 364-368). Widać więc, że analizowany termin nadal dotyczy tych samych krajów co we wcześniejszym okresie, jedyna zmiana dotyczy pojawienia się Chin, o których nie było jeszcze mowy w średniowieczu, baroku i renesansie.

\section{Okres romantyczny}

Zgodnie z definicją ze Słownika literatury polskiej XIX wieku pod redakcją Józefa Bachórza i Aliny Kowalczykowej orient jest synonimem wschodu, ale wschód jest tutaj rozumiany jako wzór kulturowy opozycyjny wobec zachodu, a dokładniej jego tradycji reprezentowanych przez klasycyzm i racjonalizm (Piwińska (red. Bachórz, Kowalczykowa) 1994: 655-660).

Pod względem geograficznym orientalne to w dalszym ciągu dotyczące kultury krajów muzułmańskich, ze szczególnym uwzględnieniem Turcji i Mongolii, która nadal pozostaje właściwie jedynym ujęciem Dalekiego Wschodu. Ponownie pojawia się Krym, silnie utrwalony przez twórczość Adama Mickiewicza, w szczególności w Sonetach krymskich, występuje również Egipt. W tym okresie nastąpiło rozszerzenie obszaru orientu o tak zwany orient sarmacki, który stanowiły kresy wschodnie Rzeczypospolitej. Ujęcie to zostało zobrazowane w literaturze, w utworach takich jak Maria Antoniego Malczewskiego czy Zamek kaniowski Seweryna Goszczyńskiego, przez co silnie utrwaliło się w polskiej mentalności (Piwińska (red. Bachórz, Kowalczykowa) 1994: 659).

Okres romantyczny przyniósł jednak coś więcej niż tylko uaktualnienie profilu geograficznego. To w tym czasie doszło do silnej ideologizacji terminu, której pokłosie możemy zaobserwować w polszczyźnie do dziś. Orientalizm pod względem ideologicznym oznaczał $\mathrm{w}$ romantyzmie pęd do prymitywizmu, do dziewiczej przyrody i do postaci człowieka naturalnego, którego reprezentacją był „Arab na pustyni” (Piwińska (red. Bachórz, Kowalczykowa) 1994: 657) mający obrazować przekonanie, że „ludy wchodu żyją w stanie naturalnym” (Piwińska (red. Bachórz, Kowalczykowa) 1994: 657). Orient miał być czymś dzikim, niezwykłym, obcym w sposób niezwykły i przyciągający, choć niejednokrotnie odstręczający ze względu na swoją inność. Zdaniem romantyków w nieznanych stronach świata kryła się pozarozumowa mądrość najstarszej tradycji oraz wieczna twórcza głębia. Orient reprezentował kulturę inną, lepszą, cenioną najwyżej i noszącą znamiona transcendencji. Wiązał się z tajemnicą, czymś fantastycznym, ezoterycznym i przede wszystkim nieracjonalnym, stanowiącym polarne przeciwieństwo kultury zachodniej, jej całkowite zaprzeczenie. Wschód w romantycznej perspektywie stanowił synonim ukrytej, wewnętrznej, zagadkowej i często demonizowanej ciemnej strony ludzkiego ,ja" — pierwotnego i żyjącego w zgo- 
dzie z naturą. Był również traktowany jako kraina ze snu, miejsce wewnętrznego bogactwa, mistycznych przeżyć i duchowych podróży. Niejednokrotnie wiązał się z szaleństwem, wolnością i głębią doznań powiązaną z nieuleganiem normom moralnym i społecznym. Miał reprezentować to, co cywilizowany świat zachodu dawno utracił; inne normy moralne, pojawiające się szczególnie w odniesieniu do Siczy Kozackiej i panujących wśród jej mieszkańców obyczajów (Piwińska (red. Bachórz, Kowalczykowa) 1994: 658).

Ze szczególnym ujęciem orientu i orientalizmu spotykamy się u Juliusza Słowackiego w jego utworze Lambro z 1833 roku. Orient jest tam reprezentowany przez wschód turecki, silnie zaznaczone zostały zmysłowość cielesna oraz porywczość i okrucieństwo. Ważnym elementem wprowadzonym przez Słowackiego jest też przepych dekoracyjny opisywanej przestrzeni, co miało silny wpływ na późniejszych twórców modernistycznych i rozwój nurtów dekadenckich (Piwińska (red. Bachórz, Kowalczykowa) 1994: 658).

Poza Turcją Słowacki opisywał w swoich dziełach ponadto wyobrażenie o wschodzie starożytnym reprezentowanym przez Egipt i Indie. U innych twórców również pojawiały się obrazowania orientu jako silnie zmitologizowanego wschodu indyjskiego i indyjsko-aryjskiego, a także wschód mongolsko-azjatycki, którym szczególnie fascynował się Adam Mickiewicz, czemu dał upust w prelekcjach paryskich, czy wreszcie wschód reprezentowany przez imperium rosyjskie (Piwińska (red. Bachórz, Kowalczykowa) 1994: 658).

W romantyzmie orient wartościowany jest w sposób zdecydowanie dodatni. To, co orientalne, jest wspaniałe, niezwykłe i pociągające. W kolejnych latach nastąpił okres rzeczywistych i bezpośrednich kontaktów z tak idealizowanymi przez romantyków krajami orientu muzułmańskiego. W wyniku ich poznania i zderzenia z panującymi w nich realiami - marazmem kulturalnym, despotyzmem politycznym i powszechnie panującą nędzą — doszło do demitologizacji romantycznej wizji orientu i stopniowo wygasało zainteresowania wschodem. Do zmiany obrazowania orientu z pozytywnego na negatywny przyczyniły się też relacje emigrantów i zesłańców, a także kształtujący się w kraju nurt pozytywistyczny będący z założenia okcydentalny i stojący w opozycji do romantyzmu. W ich postrzeganiu wschód stanowił niekiedy wręcz zagrożenie dla kultury narodowej, co zahamowało proces zbytniej orientalizacji polskiej kultury (Piwińska (red. Bachórz, Kowalczykowa) 1994: 658-659).

Mimo zmiany postrzegania orientu przez pozytywistów, a także twórców młodopolskich, którzy szczególnie chętnie odwoływali się do etosu japońskiego wojownika, będącego dla nich wzorem bohaterstwa (Podraza-Kwiatkowska 1983: 82), silna eksploatacja motywów orientalnych w romantyzmie sprawiła, że to właśnie romantyczny sposób ujęcia analizowanego terminu jest najbardziej rozpoznawany i stanowi podstawę współczesnego sposobu postrzegania tego, co orientalne. Dzisiejszy obraz orientu w języku polskim niewątpliwie nawiązuje do obrazu obecnego w epoce romantyzmu. W związku z demitologizacją wschodu 
muzułmańskiego nastąpiło jednak przesunięcie granic orientu dalej na wschód, w kierunku Azji Południowo-Wschodniej, co zdają się potwierdzać użycia tego terminu i jego derywatów we współczesnym języku polskim.

\section{Współczesne ujęcia}

W celu zbadania współczesnego sposobu użycia analizowanych w artykule terminów w pierwszej kolejności najlepiej sięgnąć do Narodowego Korpusu Języka Polskiego dostępnego w formie platformy internetowej. W obrębie korpusu składającego się z ponad 240 milionów słów odnotowano 957 użyć terminu orient i wszystkich jego derywatów. Główne użycia dotyczą Orient Expresu, czyli pociągu z Paryża do Stambułu, opisanego w literaturze przez Agathę Christie w książce pod tym samym tytułem, a następnie utrwalonego w kulturze licznymi ekranizacjami. Odnośnie do prowadzonych badań tego typu użycie terminu orient niewiele wnosi do jego obrazowania. Dalsze użycia rzucają więcej światła i prezentują zaktualizowany profil geograficzny orientu w języku polskim. Pojęcie to wciąż odnosi się do tego, co muzułmańskie, związane ze światem islamu, do Turcji, Bliskiego Wschodu, Indii, Uzbekistanu i Kaszmiru, a także do Afryki Północnej, ze szczególnym uwzględnieniem Egiptu i Maroka. Daleki Wschód reprezentowany jest przez Chiny i Japonię, które najczęściej pojawiają się w kontekście wierzeń religijnych i filozofii, szczególnie taoizmu, shintoizmu i konfucjanizmu oraz kulinariów, przede wszystkim sushi i potraw kuchni chińskiej. Osobno można znaleźć w korpusie zapis o orientalnych religiach, czyli taoizmie, buddyzmie i innych spośród wielu religii Indii (Narodowy Korpus...).

Wśród głównych współczesnych użyć i kolokacji dla przymiotnika orientalny występują rzeczowniki: język, kuchnia, przyprawa, bar i restauracja, a także muzyka, religia i zapach, w większości w odniesieniu do krajów dalekowschodnich. Termin orient i jego derywaty występują przede wszystkim w prasie oraz literaturze, rzadziej w internecie. Głównie pojawiają się w reportażach i publikacjach o tematyce podróżniczej. Dane uzyskane poprzez badanie Narodowego Korpusu Języka Polskiego nie są oczywiście w pełni jednoznaczne, co jest spowodowane powracającym w badaniach językoznawczych problemem rzeczywistej reprezentatywności korpusów, stanowią jednak pewną podstawę i mogą wyznaczać kierunek zmian zachodzących w języku.

Od czasów staropolskich do romantyzmu włącznie pod pojęciem orientu rozumiano głównie Bliski Wschód reprezentowany przez kraje muzułmańskie, kraje Dalekiego Wschodu pojawiały się znacznie rzadziej i były o wiele skromniej reprezentowane w powstającej literaturze. Obecnie wydaje się, że proporcje zostały odwrócone, a granica orientu zaczęła się przesuwać dalej na wschód, w kierunku Azji Południowej i Wschodniej, co potwierdzają przykłady użycia 
z Narodowego Korpusu Języka Polskiego, w których nacisk kładziony jest przede wszystkim na chińskie i japońskie kulinaria, religie i filozofie. Ten stan rzeczy oddaje również definicja zamieszczona w Stowosieci, czyli internetowym słowniku tworzonym od 2005 roku przez zespół Politechniki Wrocławskiej, w której orient został opisany jako „kraje wschodniej i południowej Azji, traktowane jako całość geograficzno-kulturowa”, a jego synonimami są „Azja” i „Wschód” (Stowosieć). W przeciwieństwie do klasycznych definicji słownikowych przytoczonych w podpunkcie pierwszym prezentowanego artykułu, definicja Stowosieci nie wspomina o Bliskim Wschodzie i wschodzie arabskim, stosując silne ograniczenie geograficzne.

O zmianie profilu analizowanego terminu mogą też świadczyć wyszukiwania Google - po wpisaniu w wyszukiwarkę słowa orient lub jego derywatów w głównej mierze pojawiają się wyniki dotyczące kuchni orientalnej, co dokładniej oznacza kuchnię głównie chińską, wietnamską i tajską, czasami japońską, a więc krajów Azji Południowo-Wschodniej. Wśród wyników wyszukiwania rzadziej pojawiają się orientalne koty i dywany, które reprezentują Persję, czyli dawniejsze ujęcie orientu, powszechne w poprzednich epokach. Najrzadsze wyniki dotyczą różnego typu kosmetyków, które jednak również pochodzą głównie z Azji Wschodniej, choć niekiedy także z Indii i Bliskiego Wschodu.

\section{Podsumowanie}

Zaprezentowana $\mathrm{w}$ artykule analiza definicji terminu orient $\mathrm{i}$ jego derywatów w encyklopediach języka polskiego, różnych słownikach: ogólnych języka polskiego, synonimów i wyrazów bliskoznacznych, wyrazów obcych, etymologicznych oraz słownikach terminów literackich i słownikach literatury: staropolskiej, oświecenia, XIX i XX wieku, a także tych pochodzących z Wielkiego Słownika Języka Polskiego i Słowosieci wskazuje na zmianę, jaka zaszła w językowym obrazie orientu w polszczyźnie. Wniosek ten potwierdzają także narzędzia dostępne w internecie: Narodowy Korpus Języka Polskiego i wyszukiwarka Google.

Zmiany zachodzące $\mathrm{w}$ sposobie postrzegania orientu dotyczą przede wszystkim obszaru geograficznego. Przez stulecia przymiotnik orientalny odnosił się do niezwykle różnorodnego pod względem kulturowym i szerokiego obszaru, począwszy od Afryki, przez Bliski Wschód, na Dalekim Wschodzie kończąc. Po wnikliwej analizie zebranych definicji na pierwszy plan wysuwa się ta ze Stownika wyrazów bliskoznacznych Anny Kubisy-Ślipko, w której to, co orientalne, miało być antonimiczne do tego, co lokalne (Kubisa-Ślipko 2000: 57). Wydaje się bowiem, że przez wieki dla użytkowników języka polskiego orientem było wszystko, co inne niż rodzime, lokalne, ,nasze”. Orientalna była odmienność obyczajowa i kulturalna, często postrzegana jako dzika, pierwotna, niejednokrotnie fantastyczna, magiczna. 
Do dziś większość sposobów postrzegania orientu przetrwała w obrębie znaczenia tego terminu i jego derywatów występujących w języku polskim. Wciąż niezwykle silna jest romantyczna wizja tajemniczej krainy pachnącej przyprawami, dalekiej, wręcz mitycznej. Nadal główną rolę odgrywa odległość geograficzna i - przede wszystkim — inność, opozycyjność do tego, co lokalne, swojskie. Dostrzega się jednak wyraźne oddalenie orientu z Bliskiego i Środkowego Wschodu na Daleki Wschód - do Azji Południowej i Wschodniej. Może być to spowodowane postępującym rozwojem technologicznym umożliwiającym ludziom podróże, przez co zmienia się perspektywa w postrzeganiu tego, co jest dalekie, a co bliskie, a w efekcie tego, co lokalne, a co orientalne.

\section{Bibliografia}

Bańkowski A. (2000), Etymologiczny słownik języka polskiego, t. 2, Warszawa.

Bartmiński J. (2013), Językowe podstawy obrazu świata, Lublin.

Kubisa-Ślipko A. (2000), Słownik wyrazów bliskoznacznych, Wałbrzych.

Kurzowa Z. (2000), Stownik synonimów polskich, Warszawa.

Majewska B. (1990), Orientalne inspiracje literatury oraz Wschód w kulturze i piśmiennictwie, [w:] Stownik literatury staropolskiej, red. T. Michałowska, Wrocław.

Markowski A., Pawelec R. (2007), Wielki słownik wyrazów obcych i trudnych, Warszawa.

Piwińska M. (1994), Orientalizm, [hasło w:] Słownik literatury polskiej XIX wieku, red. J. Bachórz, A. Kowalczykowa, Wrocław, s. 655-660.

Podraza-Kwiatkowska M. (1983), Inspiracje japońskie w literaturze Młodej Polski: rekonesans, „Pamiętnik Literacki”, z. 74/2, s. 61-82.

Reychman J. (1996), Orientalizm, [hasło w:] Stownik literatury polskiego oświecenia, red. T. Kostkiewiczowa, Wrocław.

Sławiński J. (2000), Stownik terminów literackich, Wrocław, s. 58, 361.

Urbańczyk S. (1992), Encyklopedia języka polskiego, Wrocław.

\section{Źródła internetowe}

Google (google.pl).

Narodowy Korpus Języka Polskiego (www.nkjp.pl).

Stowosieć (plwordnet.pwr.wroc.pl).

Wielki stownik języka polskiego (wsjp.pl). 


\section{The Orient in Polish: An image of the Orient in Polish lexicography}

\section{Summary}

The article focuses on the study of the meaning, occurrence and use of the term Orient and its derivatives - associated words related to it — in the Polish language.

The starting point is the concept of a linguistic image of the world that assumes the dependence of the individual's perception of reality on the language he or she uses. A person, learning about the world, experiences it with the help of native speech, which imposes a certain specific way of thinking. The language appears as a filter and a ready set of interpretive schemes that impose a specific point of view on the user.

The aim of the presented research is the reconstruction of the linguistic image of the non-linguistic reality section represented by the Orient lexeme and its derivatives.

The study covered the National Corpus of the Polish Language, more widely available dictionary and encyclopedic definitions, and types of usage that can be observed in the contemporary public space represented by the so-called old and new media. The article also focuses on the connotations of the word Orient appearing in the Polish language system. An important part of the research focuses on the functioning of the analyzed lexeme and its derivatives in Polish culture, taking into account the changes taking place. The observed changes were separated and described, then presented in a chronological manner.

The presented analysis creates the possibility of a better understanding of the perception of the Orient by people speaking Polish.

Keywords: Orient, Orientalism, Polish language, lexicography 